\title{
Intersection Principles Between Islamic And International Humanitarian Law
}

\author{
Himmah A'la Rufaida \\ Universitas Lampung \\ Email: himmah8@gmail.com \\ Rudi Natamiharja \\ Universitas Lampung \\ Email : rudi.natamiharja@fh.unila.ac.id
}

\begin{abstract}
The universal nature as inherent in Islamic Law and International Humanitarian Law makes these two laws often compared. The comparison in terms of the principles between the two legal instruments is interesting, considering they both originate from two poles of thought which are always competing and without being insulated by space. There is no law that is permanent and final, that is what happened to those two legal methods. Law develops according to the era without reducing values. Islamic values were born much earlier than International Humanitarian Law. The basic principles of Islamic Law concerning the relationship of humanity in society between nations and nations during wars have become a strong foundation for international humanitarian law norms. For example, such as legal principles that contain the principles of equality, freedom, peace, humanity and so on.
\end{abstract}

Keywords : Legal principles, Islamic Law, International Humanitarian Law.

\begin{abstract}
Abstrak
Sifat universal sebagaimana yang melekat pada Hukum Islam dan Hukum Humaniter Internasional menjadikan kedua hukum tersebut sering dibandingkan. Perbandingan dari segi prinsip-prinsip antara dua instrumen hukum tersebut sangat menarik mengingat keduanya datang dari dua kutub pemikiran yang selalu bersaing dan tanpa tersekat oleh ruang. Tidak ada hukum yang bersifat tetap dan final, itu pun yang dialami oleh kedua kaedah hukum tersebut. Hukum berkembang sesuai dengan zamannya tanpa mengurangi nilai-nilai. Nilai-nilai islam lahir jauh lebih dahulu dari pada Hukum Humaniter Internasional. Prinsipprinsip dasar Hukum Islam tentang hubungan umat manusia dalam masyarakat antar bangsa dan negara pada saat perang telah menjadi landasan yang kuat bagi norma hukum humaniter internasional. Misalnya seperti prinsip hukum yang mengandung asas persamaan, kebebasan, perdamaian, humanity dan lain sebagainya.
\end{abstract}


Kata Kunci : Prinsip-prinsip hukum, Hukum Islam, Hukum Humaniter Internasional.

Website : http://e-journal.metrouniv.ac.id/index.php/istinbath/index

Received : 2019-10-07. Published : 2019-12-31.

This is an open access article distributed under the terms of the Creative Commons Attribution 4.0 International License, which permits unrestricted use, distribution, and reproduction in any medium, provided the original work is properly cited.

\section{Introduction}

The universal nature as inherent in Islamic Law and International Humanitarian Law makes these two laws often compared. The International Humanitarian Law (IHL) is part of international (public) law which for humanitarian reasons was formed in order to limit the rights of conflicting parties in the selection of tools and procedures for war. In addition, IHL also provides protection to people and property rights that are affected or are most likely to be affected by the conflict. ${ }^{1}$

Jean Pictet defines IHL as constitutional legal provision, whether written and customary, ensuring respect for individuals and his well being. Geza Herzeg defines IHL as part of the rule of public international law which serves as the protection of individuals in times of armed conflict. Its place is beside the norm of warfare, it is closely related to them, but it must clearly distinguish from these, its purpose and spirit are different. Esbjorn Rosenbland said IHL was related to the beginning and ending of the dispute; occupation of the enemy territory; relations between parties to the neutral state. While the Law of Warfare includes, among others, methods and means of war, combatant status, protection of the sick, prisoners of war and civilians. In addition, Mochtar Kusumaatmadja also gave his definition of IHL, which is part of the law governing the provisions of the protection of victims of war,

\footnotetext{
${ }^{1}$ Buletin ICRC, Hukum Humaniter Internasional (Menjawab Pertanyaan-pertanyaan Anda), Jakarta: ICRC, 2004. page. 4.
} 
different from the laws of war governing the war itself and everything related to how to conduct the war itself. ${ }^{2}$

Looking at the definitions that have been revealed by experts, it can be concluded that

IHL is a set of rules which for humanitarian reasons are made to limit the consequences of armed disputes. This law protects those who are not or no longer involved in disputes and limits the methods and methods of warfare. The main objective is to reduce and prevent human suffering in times of armed conflict. These rules must be obeyed not only by the government and the armed forces but also by armed resistance groups and every party involved in a conflict.

Not only IHL, Islamic Law also regulates humanitarian law (the law of war) and has a strong influence and even serves as the main source of law enforcement in several countries. The Islamic Legal System that was born more than 1400 years ago has also been recognized by the international community and has a position equal to the existing legal system in the world. Although Islamic Law and IHL were born at two different periods, it cannot be denied that up to now these two legal systems are often pitted and debated by both sides of their followers. This paper does not intend to raise the various conflicts that are spread between the two legal systems. But on the contrary, the author intends to raise any principles related to IHL that are also recognized and have existed and lived in Islamic Law until now.

\section{Result And Discussion}

\section{Universality of Islamic Law as the Basis of International Relations: A Comparison with International Humanitarian Law}

IHL has a long journey that starts from the first Geneva Convention in 1864 concerning the improvement of the conditions of the wounded victims of army personnel on the battlefield. The trip has lasted approximately 130 years since the issuance of several agreements that gave birth to rules to protect victims of armed conflict and limit the methods and instruments of war until the establishment of a permanent International Criminal Court by the Rome Statute of 1998. All of these agreements aim to reduce the impact of war on individuals and objects. Although IHL has the same objective as International Human Rights

\footnotetext{
${ }^{2}$ Haryomataram, Hukum Humaniter, Jakarta: Rajawali Press, 1994. page.15-25.
} 
Law, which is to protect human honor, IHL is only applied to conditions of international and non-international armed conflict.

The great values contained by IHL are in line with the values that were brought by Samawi religion (which originated from God's revelation) which were handed down as a blessing for humanity and to glorify humanity, self-improvement and the creation of a just peace for all parties. Islam as one of the religions that greatly influences IHL and has been recognized internationally, so that it becomes a source of law in IHL provides many concepts about war at this time.

Islamic law was born through the existence of the Islamic religion which originated from the Al-Qur'an and the customs of the Prophet Muhammad SAW that had been codified. The two main sources of Islamic law are the main foundation in the grand norm system. To complement these two main sources, there are doctrines from Islamic religious leaders that can be recognized as legal sources as long as they do not conflict with the two main sources. This doctrine is known as 'Ijtima'. Both individually and collectively.

As a celestial religion, Islam initially functioned as a way of life for individuals and groups. In line with the times, the existence of Islamic principles is also recognized by the state. For example, Saudi Arabia, Iran, Pakistan, Malaysia, and Brunei Darussalam are countries that set Islamic values as guidelines in their state and relations with other countries. This is confirmed in their respective constitutions. Thus Islamic law becomes the law that governs human life in the world. Therefore, Islamic law which is part of the Islamic religion is a law that is natural (universal), not only local or national.

It can be understood that Islamic law, in the beginning, regulates human conduct in the framework of friendship and cooperation between one nation and another in all aspects of life, to meet the needs of each, in the life of the nation and state. The basis of Islamic law as an international regulation refers to the view of perfect humanity, where Islam places human rights with great dignity in proportion to the creation of human nature itself.

\section{International Principles In Islamic Law}

Based on the discussion in the previous paragraph, Islamic law regulates religious matters and also regulates social problems. This means that Islamic law functions as a basis 
for worship and as a basis for law and character that regulates relations between human beings. Even Islamic law not only lays the foundation of the relationship in the narrow sense but covers all aspects of life.

Islamic law upholds "huquq al-insaniyyah" without recognizing religious discrimination, skin color, and nationality. This is stated in the principles of Human Rights (HAM) listed in the International Declaration of Human Rights. More broadly, Islamic Law calls for all human beings of different origin and nationality, color and religion, to uphold the fraternity of humanity as a whole so that humanism is truly manifested in the lives of humanity. The principle of peace is also contained in the UN Charter and becomes the foundation of international relations that is highly prioritized. The values of humanitarian law in Islamic law are also clearly exposed. Islamic law regulates the relationship between nation and state, both in times of peace and in times of war. In fact, to establish an international body tasked with resolving the dispute that occurred between them. If there is a nation and state that does not want to submit, then with the strength of the body can force to resolve disputes that occur, for the sake of upholding the truth and ensuring justice.

The principles of Islamic Law related to IHL emphasize more on moral and ethical values because the awareness demands to submit to religious norms, because "akhlaq alkarimah" is used as the main foundation for the establishment of Islamic Law. For more details, the following principles will be put forward about Islamic law related to international relations, especially relating to International Humanity Law.

\section{The Principle Of Equality}

The principle of equality (equal rights) is a fundamental principle in International law, including in IHL. Article 12 Geneva Convention II for the Improvement of the Situation of Members of the Armed Forces in Injured, Sick and Sunken Victims states:

"Members of the army and others referred to in the following article, who are injured or sick, must be respected and protected in all circumstances. They (members of the parties to the conflict) must be treated humanely and be treated by the disputing party in the authority of whoever they are, without any adverse discrimination based on gender, ethnicity, nationality, religion, opinions (ideology) politics, or other similar criteria". 
Whereas Islamic Law confirms this principle in "Al-Qur'an Qs.An-Nisaa" verse 1 which means:

"O, people! Be fearful of your Lord who created you from oneself (Adam) and (Allah) created his partner (Eve) from his (self), and from both of them, God (Allah) multiplied many men and women. Fear God (Allah) who in His name you ask one another, and (maintain) family relations. Surely Allah always takes care and watches over you".

"Mutawatir" hadiths also affirm that equality applies to all. In the Hajj Wada sermon, the Prophet SAW stated:

"O people, your Lord is One. All of you are Adam's children and grandchildren. Adam was created from the ground. There are no privileges and discrimination between Arabs and non-people; between white people and red people, except for piety" (Narrated by Al-Bukhari and Muslim).

Therefore, both the "Al-Qur'an" and the Geneva Conventions emphasize the importance of the principle of equality in human relations, especially for people who are isolated due to war.

\section{Principle Of Justice}

Referring to the opinions of Kevin Hodges and Daniel quoted by Emmy Latifah, justice contains universal moral values which are the basic rights and needs of people throughout the world. ${ }^{3}$ The principle of justice in international humanitarian law also comes from general principles namely the UN Charter and the universal declaration of human rights. Everyone must get the same treatment regardless of skin color or nationality. Every country gets the same position in front of the law regardless of developed or developing countries. Thomas Aquinas classifies justice into two, first general justice that is justice according to the will of the law that must be carried out in the public interest, secondly special justice, namely a justice based on the principle of proportionality.

\footnotetext{
${ }^{3}$ Emmy Latifah, Eksistensi Prinsip-prinsip Keadilan dalam Sistem Hukum Perdagangan Internasional, Volume 2 Nomor 1, Bandung: Padjajaran Jurnal Ilmu Hukum, 2015. page.65.
} 
Al-Qur'an emphasizes that it is mandatory to apply justice, although the implication of a believer must enforce legal justice against himself or against his enemies by fighting close relatives such as parents and relatives. Allah SWT says which means:

"O, believers! Be an enforcer of justice, be a witness for God (Allah), even with yourself or with your mother and father and your relatives. If he (the accused) is rich or poor, then Allah knows better the benefits (his goodness). And if you distort (words) or are reluctant to be a witness, then know Allah is careful about everything you do" (Qs.An-Nisaa verse 135).

Here it is proven that Islamic principles are in accordance with the Geneva Conventions because justice demands that the accused must be given the right to defend themselves in various ways. Article 84 Geneva Convention III concerning the Treatment of Prisoners of War states:

"A prisoner of war must never be tried by a court of any type who does not provide basic guarantees regarding freedom and impartiality, as generally recognized and especially procedures that do not give rights to the accused and the manner of defense as stated in article $105 "$.

Article 105 states that prisoners of war have the right to obtain the assistance of a fellow prisoner, the defense of a defense attorney or professional choice, present witnesses, and if deemed necessary, the services of a competent interpreter. He must be informed of his rights by the State of Detention before the trial begins.

\section{Principles of War Law}

\section{a. Warring Ethics}

International humanitarian law was not created to stop or legalize war. However, to arrange for the war to emphasize more human values. This is because the war will never end as proven by history.War in Islam is a war of defense, which aims to resist attacks and secure the implementation of da'wah. War must stop if the intended purpose has been achieved. If the enemy attacks have stopped and they are inclined towards peace, then Muslims must accept the peace, either in the form of a ceasefire or in the form of making agreements. When war is ongoing, soldiers are not 
permitted to kill women, children and the elderly. Besides, it is not permissible to chop enemy corpses, instead they are required to cover their genitals. When the war is over, all bodies must be buried in honor of humanity.

In IHL, this is included in the principle of distinction in which the disputing party must be able to distinguish between combatants and civilians. Because civilians must not be attacked and must be protected. Protection of civilians is regulated in Geneva Convention IV concerning Protection of Civilians in Wartime.

\section{b. Ban On Killing}

War in Islam highly respects and pays attention to the principles of humanity and human rights. The fundamental right of human rights is the right to life. Allah SWT confirms in the Al-Qur'an Qs.Al-Maidah verse 32 how the right to life of humans must be guaranteed and respected, and Islam forbids the killing of fellow human beings.

"... whoever kills someone, not because that person killed someone else, or not because he did mischief on earth, as if he had killed all humans. Whoever preserves the life of a human being, as if he has preserved the lives of all humans ... ".

Then in Qs.Al-An'am verse 151 is reiterated:

"... And do not kill souls that are forbidden by Allah, except with the right reasons "

Murder in Islam is a grave sin as confirmed in the Hadith of the Prophet Muhammad SAW which states:

"The greatest sins are associating things with God(Allah) and killing people."4

Both in the Al-Qur'an and the Hadith above, the word "life" (nafs) is used in a general sense without any distinction or specificity. This prohibition applies to all

\footnotetext{
${ }^{4}$ Maulana Abul A'la Maududi, Hak Asasi Manusia dalam Islam, Palembang: Bumi Aksara, 1976. page. 22.
} 
humanity. ${ }^{5}$ The issue of revoking a person's life as punishment for murder and for acts that cause damage on earth can only be decided by the competent judicial authority.

On December 9, 1945, the UN General Assembly approved a convention banning mass killings based on national, ethnic, racial or religious sentiments, namely the Convention on the Prevention and Punishment of the Crime of Genocide or better known as the Genocide Convention. This convention was born after humanity witnessed the atrocities of the German National-Socialists (Nazis) carrying out mass killings of people of Jewish descent before World War II. In a short time, approximately eight million Jews were killed6. To prevent a repeat of similar incidents in various forms and manifestations, the Genocide Convention was made. This is related to the IHL principle about the prohibition of causing unnecessary suffering. This principle is related to the provisions which stipulate that the correct method of warfare is a method implemented only to weaken the military strength of the opposing forces.

\section{c. Protection of Civilians in War}

International law scholars acknowledge that the contribution of Islamic law, especially to war / humanitarian law is very large, especially in placing the principles of humanity in the law of war. ${ }^{6}$ A professor of international law at the State Academy of Sciences in The Hague, Netherlands, stated that people who were considered as laying the foundations of international law namely Vittoria and Suarez took many of the basics of international law in Islamic law. Then Grotius (Hugo de Groot) as stated above is considered to be the "father" of modern international law, quoting Vittoria and Suarez's opinions, which have been influenced by Islamic law. Michel de Tubb underlines the principles of Islamic Law, especially those related to the laws of war. In this case, he delivered the message of Abu Bakr to the commander of the first army

\footnotetext{
${ }^{5}$ Maulana Abul A'la Maududi, Hak Asasi Manusia

${ }^{6}$ Oppenheim-Lauterpacht, International Law, Vol. I-Peace, 8th ed., London: Longmans, Green \& Co, 1955. page.749-750.
} 
sent to Syria after "Rasulullah SAW" died. Likewise the orders of "Khalifah AlHakim bin Abdur- Rahman" in 963 in Cordova. ${ }^{7}$

The same opinion was also expressed by the French author Sedilot in his book Arabic History, ${ }^{8}$ Jean Pictet in his writings "The Geneva Convention and the Laws of War", ${ }^{9}$ MKEreksoussi in his writings "The Qu'ran and The Humanitarian Convention"10 and Mochtar Kusumaatmadja in his book Convention - Geneva Convention 1949 Concerning Protection of War Victims. ${ }^{11}$ In explaining how Islamic Shari'ah strongly emphasizes the principle of humanity in the law of war, Jean Pictet states:

"In the Crusades, for example, Muslims were more humane than their opponents". ${ }^{12}$

Provisions for the protection of civilians during war which are regulated in IHL are also regulated in the Geneva IV Convention on the Protection of Civilians at the Time of War 1949, which consists of 159 articles which as a whole regulates the protection of the rights of civil society as a whole from the impacts by war.

Protection of the civilian population from the enemy in Islam has been affirmed both by "Rasulullah SAW" and by the "khalifah". "Rasulullah SAW" always warns his friends who will go to war:

"Depart with the name 'Allah', and with the blessing 'His Rasul'; you must never kill old men, children, and women". (Narrated by Abu Dawud)

"Do not kill children and workers ('Asif) ". ${ }^{13}$

Furthermore, khalifah Abu Bakr gave a message to 'Commander Usamah bin Zaid': "Do not betray, do not overdo it, do not break promises, do not mince corpses of

\footnotetext{
${ }^{7}$ Kumpulan Kuliah Michel de Tubb tahun 1926, jilid I, dikutip dari Ali Ali Mansur, Syari'at Islam dan Hukum Internasional Umum, alih bahasa oleh Muhammad Zein Hassan, Lc.Lt., Jakarta: Bulan Bintang, 1973. page. 42.

${ }^{8}$ Kumpulan Kuliah Michel de Tubb

${ }^{9}$ Revue International de la Croix Rouge, 1962, page. 295; dikutip dari Mochtar Kusumaatmadja, KonvensiKonvensi Jenewa 1949 Mengenai Perlindungan Korban Perang, Jakarta: Bina Cipta, 1986. page.7and 9.

${ }^{10}$ International Review of the Red Cross, Jenewa: ICRC, 1962. page. 273-279.

${ }^{11}$ International Review of the Red Cross..

${ }^{12}$ International Review of the Red Cross..

${ }^{13}$ Ali Mansur, ..
} 
enemies, do not kill small children, nor parents, and not Ladies, don't cut down palm trees, don't burn and cut fruitful wood, don't slaughter goats, cows, and camels except for food".

Likewise his message to the 'Commander Yazid bin Abu Sufyan'. ${ }^{14}$ 'Khalifah Umar bin Khattab' and 'Khalifah-Khalifah' next always hold to the principles above if they are forced to face war. Furthermore, Islamic jurists further elaborated these principles as carried out by 'Al Auza'i' and 'Imam Malik'. They stated that it was forbidden to kill enemy women and children, if the enemy made them shields, even if the enemy placed the women and children in front of them to be a deterrent and shield. Based on the mandate of 'Abu Bakr' above, 'Al Auza'i' argues that Muslims should not do anything that will destroy the enemy country (darul harb), because it is damage (facade). ${ }^{15}$

\section{d. Treatmen Of Enemy Soldiers}

Islam is also very concerned about the rights of injured or dead enemy soldiers (combatants) on the battlefield. In this case, the Prophet Muhammad said:

"Do not attack an enemy that has been injured"16

"Fire punishment does not have the right to do anything but the Lord of Fire"

"Do not cut out enemy's corpse"17

Those hadiths affirm that Islamic Law does not justify carrying out actions that cause unnecessary or inhumane suffering, even to the enemy.

In the IHL, the main rules that relate to this are the prohibition of wounded combatants from the enemy with punishment, injuring, torture, and poor handling of these combatants can no longer fight, either by shooting, there are no weapons that can be used for personal use. This are the general rules of IHL that can be found in article 23 (c). The Hague Commission in 1907, which was later confirmed by article 41 of Additional Protocol I and Article 4 of Additional Protocol II.

\footnotetext{
${ }^{14}$ Ali Mansur, ..

${ }^{15}$ Ali Mansur, ..

${ }^{16}$ Abul A'la Maududi, ... page. 74.

${ }^{17}$ Abul A'la Maududi, ... page. 74.
} 
Another important rule regarding the treatment of enemy personnel is the prohibition of deception and fraud as a way to kill, injure or arrest the enemy. This rule can be found in articles 23 and 24 of the Hague Convention in 1907, which is set forth in article 37 of Additional Protocol I. The IHL distinguishes between permissible tactics of war (khadi'ah) and prohibited acts of treason (ghadr). Ghadr as defined in supplementary protocol I mean "action that invites the opponent's confidence so the opposing party believes they have the right or obliged to get protection with the intention to betray".

\section{e. Prisoner Of War}

Regarding treatments of prisoners of war as regulated in the Third Geneva Convention in 1949, Islamic Law has the foundation. Every prisoner of war was killed. In the Jewish scriptures, the Talmid was accepted not only to oppose the war being canceled, but also by a woman, children, and animals in the occupied territories enemy. Also that Roman and Greek was fought as a war aimed at harnessing energy. ${ }^{18}$ Islamic Law forbids prisoners of war from being killed or treated inhumanely. Prophet Muhammad said: "Prisoner of war must not be killed at all". ${ }^{19}$ Islam has two choices, liberating with compensation(fida) or free up without ransom (manna). The first choice was treated by Prophet Muhammad during the Battle of Badr, while the second choice was treated by Prophet Muhammad when there were liberating Mecca. Prophet Muhammad stated:

"When you meet with infidels (on the battlefield), beat their necks. Then, if you have defeated them, hold them their necks and after that, you may release them or receive a ransom until the war is over".

Regarding the issue of ransom, Imam Syafi'i argues that the ransom can be change into wealth or with prisoners again. ${ }^{20}$ That is referred to as IHL as "the exchange of prisoners of war". Quran strongly recommends that prisoners of war be approved as well as possible. Al-Insan in Quran verse 8 shows that good Muslims (Al-Abrar):

\footnotetext{
${ }^{18}$ Ali Ali Mansur, .., page.76.

${ }^{19}$ Abul A'la Maududi, ... page.75

${ }^{20}$ Ali Ali Mansur, ..., page.78-79.
} 
"And they give food that they like to poor people, orphans, and people who are taken, prisoners".

Prophet Muhammad said:

"Be good to the prisoners". 21

\section{f. Legitimate War}

In the IHL, we recognize there are the differences between a legal war (bellum justum) and illegitimate war. It stated in the Hague Convention in 1907. Since the 7th century, Islamic Law has distinguished between legal (masyru'ah wa 'adilah) and illegitimate war (ghiaru masyru'ah). A legal war according to Islamic Law is a war that in the context of self-defense.

Even though for 13 years the Muslims were under attack and pressure from the Quraysh and the followers of the Prophet Muhammad that asked to revenge, the Prophet continued to be patient because he had not asked God for permission for war. After that, Prophet and his followers had to migrate to Medina and the polytheists had mobilized to attack him, God allowed Muslims to fight back to ward off aggression from the outside. However, God only allowed war with those who attack them. Meanwhile, illegitimate war according to Islamic Law is war that has been approved to take or be approved or failed. ${ }^{22}$

As mentioned, the Hague Convention in 1907 also distinguishes between legal war and illegitimate war. In the Hague Convention III in 1907 stated that legal war is a war:

1. To defend against attacks that have actually happened, and

2. To protect the legal rights of state which is violated by another country, without an acceptable reason

While illegitimate war is a war that is intended for the expansion of territory, the expansion of influence, and the desire to rule and occupy other countries.

\footnotetext{
${ }^{21}$ Ali Ali Mansur, ... page. 85.

${ }^{22}$ Ali Ali Mansur, ..., page. 51.
} 


\section{Conclusion}

Islamic Law and International Humanitarian Law are two legal systems that are still alive and very influential in the development of multinational regulations. Both are practiced by several countries including countries that are members of the United Nations and the Geneva Conventions. There is a common principle between Islamic Law and International Humanitarian Law. That because both legal systems prioritize human values and peace. Those laws have similarities. Although those laws have similarities, there are differences in terms of the source. Islamic Law is sourced from God with no defects, while International Humanitarian Law is sourced from humans which in the practice comes from the international agreement (between international law subjects), customary law, doctrine, and jurisprudence (judges's decisions) with permanent legal force. The implementation of Islamic Law and International Humanitarian Law during warfare is to provide fair treatment and protection for all people. The principles of equality, freedom, peace, and humanity are upheld to prevent actions that will cause unnecessary suffering as stated in the Geneva Conventions in 1949 and their additional protocols with Islamic Law that sourced from the Quran and Hadith.

\section{Table Of Contents}

Ali Ali Mansur. 1973. Syari'at Islam dan Hukum Internasional Umum. Jakarta: Bulan Bintang.

Buletin ICRC. 2004. Hukum Humaniter Internasional (Menjawab Pertanyaan- pertanyaan Anda). Jakarta: ICRC.

Emmy Latifah. 2015. Eksistensi Prinsip-prinsip Keadilan dalam Sistem Hukum Perdagangan Internasional, Volume 2 Nomor 1. Bandung: Padjajaran Jurnal Ilmu Hukum.

Haryomataram. 1994. Hukum Humaniter. Jakarta: Rajawali Press. ICRC. 1962. International Review of the Red Cross. Jenewa: ICRC.

Maulana Abul A'la Maududi. 1976. Hak Asasi Manusia dalam Islam. Palembang: Bumi Aksara.

Mochtar Kusumaatmadja. 1986. Konvensi-Konvensi Jenewa 1949 Mengenai Perlindungan Korban Perang. Jakarta: Bina Cipta.

Oppenheim Lauterpacht. 1955. International Law, Vol. I-Peace, 8th ed. London: Longmans, Green \& Co. 